\title{
ARTICLE Utilization of the Crust from Dry-aged Beef to Enhance Flavor of Beef Patties
}

OPEN ACCESS

$\begin{array}{ll}\text { Received } & \text { July 10, 2018 } \\ \text { Revised } & \text { August 9, } 2018 \\ \text { Accepted } & \text { August 10, } 2018\end{array}$

*Corresponding author: Cheorun Jo Department of Agricultural Biotechnology, Center for Food and Bioconvergence, and Research Institute of Agriculture and Life Science, Seoul National University, Seoul 08826 , Korea

Tel: $+82-2-880-4820$

Fax: +82-2-873-2271

E-mail: cheorun@snu.ac.kr

\author{
Bumjin Park ${ }^{1}$, Hae In Yong ${ }^{1}$, Juhui Choe ${ }^{1}$, and Cheorun Jo ${ }^{1,2, *}$ \\ ${ }^{1}$ Department of Agricultural Biotechnology, Center for Food and Bioconvergence, \\ and Research Institute of Agriculture and Life Science, Seoul National University, \\ Seoul 08826, Korea \\ ${ }^{2}$ Institute of Green Bio Science and Technology, Seoul National University, \\ Pyeongchang 25354, Korea
}

\begin{abstract}
The crust that inevitably forms on dry-aged beef is usually trimmed and discarded before sale. The aim of this study was to explore methods for utilizing this crust in processed meat products. Four sirloins were dry-aged for $28 \mathrm{~d}$ at $4^{\circ} \mathrm{C}(75 \%$ relative humidity). The crust obtained from the surface of the sirloins after completion of dry aging was lyophilized. Patties were prepared without added crust (control) or with $5 \% \mathrm{w} / \mathrm{w}$ crust, aerobically packaged, and stored at $4{ }^{\circ} \mathrm{C}$ for $7 \mathrm{~d}$. Electronic nose analysis indicated that the volatile profile differed significantly between the patties with and without crust. Compared to the control patties, patties containing crust had higher flavor, tenderness, juiciness, and acceptability scores in a sensory panel evaluation (all $\mathrm{p}<0.05$ ). In addition, patties with crust were less hard, gummy, and chewy than the control patties after 3 and $7 \mathrm{~d}$ of storage (all $\mathrm{p}<0.05$ ). The number of total aerobic bacteria was higher in raw patties with crust than in the control patties during the storage $(\mathrm{p}<0.05)$. However, no pathogens were detected. 2-Thiobarbituric acid reactive substance values of patties containing crust were significantly lower than those of control patties after 2 and $6 \mathrm{~d}$ of storage (both $\mathrm{p}<0.05$ ). Thus, crust from dry-aged beef can enhance the flavor by providing beefy and palatable flavor without a long period of dry aging.
\end{abstract}

Keywords beef patty, crust, dry-aged beef, electronic nose, sensory evaluation

\section{Introduction}

Beef consumption continues to increase globally, which is increasing the demand for high-quality beef and beef products (Myers and Kent, 2003; Zhang et al., 2017). Many consumers desire dry-aged beef due to its characteristic aged beefy and roasted flavor and tenderness (Oh et al., 2017). Dry aging is a well-known method to enhance meat quality, especially flavor, and is a feature of some high-end restaurants (Smith et al., 2008). In the United States, some consumers are willing to pay more for dry-aged beef than wet-aged beef (DeGeer et al., 2009; Parrish et al., 1991). Dry-aged beef is commonly produced when the beef is stored in a refrigerated condition (approximately $2^{\circ} \mathrm{C}-4^{\circ} \mathrm{C}$ ) for $1-5 \mathrm{wk}$

(C) Korean Society for Food Science of Animal Resources. This is an open access article distributed under the terms of the Creative Commons Attribution Non-Commercial License (http://creativecommons.org/licences/by-nc/3.0) which permits unrestricted non-commercial use, distribution, and reproduction in any medium, provided the original work is properly cited. 
without any packaging (Hodges et al., 1974). The meat surface directly contacts air and readily dries (Dikeman et al., 2013; Kim et al., 2016b). The surface of dry-aged meat is termed crust. The crust is considered waste and is usually trimmed off. Undesirable characteristics of crust for consumption include hardness, dryness, and presence of a large number of microorganisms (Smith et al., 2008). DeGeer et al. (2009) reported that trim loss of dry-aged beef strip loin exceeds $34 \%$ after $28 \mathrm{~d}$ of aging. The amount of discarded crust will increase as the production and consumption of dry-aged beef increases. This represents a huge economic loss.

In our preliminary study, we found that the crust from dry-aged beef contains greater antioxidant and angiotensin I converting enzyme (ACE) inhibitory activity than unaged, wet-aged, and dry-aged beef (data not shown). In addition, the crust generally has a stronger dry-aged flavor compared to the edible flesh portion of dry-aged beef, which is the most important quality attribute for consumers (Gorraiz et al., 2002). Thus, the crust might be valuable as a dry-aged flavor enhancer in meat products. However, no scientific information is available on the utilization of crust in processed meat products. The objective of the present study was to evaluate the quality properties of beef patties formulated with crust produced from dry aged beef.

\section{Materials and Methods}

\section{Preparation of patties}

Crust was obtained from four dry-aged beef sirloins (quality grade 3) obtained from approximately 21-month old castrated Holstein cattle. The meat was aged for $28 \mathrm{~d}$ in a $4^{\circ} \mathrm{C}$ refrigerator. The crust was dried in a lyophilizer (PVTFD-10K, Hanil Co., Ltd., Korea) for $17 \mathrm{~d}$. The fully dried samples were pulverized with a mortar and pestle and passed through $2 \mathrm{~mm}$ aperture sieve (Chung Gye Sang Sa, Korea) to eliminate large particles.

To manufacture beef patties, the eye of rounds were purchased from a commercial meat shop (Seoul, Korea) and ground using a meat grinder with a 6-mm pore size plate. The ground beef was used as prepared or was mixed with prepared crust sample (5\%) as summarized in Table 1. The different formulation of the beef patties with $0 \%$ and $5 \%$ crust adjusted the moisture level to compensate for patty weight to avoid any interference of other factors than treatment because moisture content in beef patty significantly affects its sensory and physicochemical quality. Thus, water was added to patties with $5 \%$ crust after calculation assumed that the water content of lean beef was approximately $70 \%$. The resulting water and protein contents of the control and crust-containing patties were similar. Each mixture was ground again with a grinder using a 3-mm pore size plate and then used to prepare beef patties (each $130 \mathrm{~g}$ ) using a patty pressure with $150 \mathrm{~mm}$ diameter and $25 \mathrm{~mm}$ height (Burger press, Spikomat Ltd., UK). The patties were manufactured from three independent batch with different days. The manufactured beef patties were aerobically packaged in a polyethylene bag $(38.5 \times 30.0 \mathrm{~cm})$ and stored for $6 \mathrm{~d}$ to analyze the lipid oxidation, electronic nose parameters, and total aerobic bacterial count every $2 \mathrm{~d}$. Other patties were stored for 0,3 , and $7 \mathrm{~d}$ for analysis of texture.

\section{Electronic nose analysis}

Beef patty samples of $5 \mathrm{~g}$ were individually placed in a $20 \mathrm{~mL}$ vial on a sample holder heated at $80^{\circ} \mathrm{C}$ for $10 \mathrm{~min}$. Volatile

Table 1. Formulation of beef patties (g)

\begin{tabular}{lccccc}
\hline Addition of crust (\%) & Lean beef & Beef fat & Salt & Water & Crust \\
0 & 2,400 & 600 & 9 & - & - \\
5 & 2,250 & 600 & 9 & 105 & 45 \\
\hline
\end{tabular}


compounds from the headspace injected into a gas chromatography-type electronic nose (Heracles II, Alpha MOS, France) equipped with dual columns (MXT-5 and 1701, Restek, USA) and a flame ionization detector (Alpha MOS). The injection volume was $5 \mathrm{~mL}$, and the initial and final trap temperatures were $40^{\circ} \mathrm{C}$ and $240^{\circ} \mathrm{C}$, respectively. The column oven temperature was initially held at $40^{\circ} \mathrm{C}$ for $5 \mathrm{~s}$, increased to $150^{\circ} \mathrm{C}$ at a rate of $0.5^{\circ} \mathrm{C} / \mathrm{s}$, increased to $260^{\circ} \mathrm{C}$ at $5^{\circ} \mathrm{C} / \mathrm{s}$, and held at $260^{\circ} \mathrm{C}$ for $30 \mathrm{~s}$. The peak area was integrated using the Alpha Soft program (Alpha MOS).

\section{Sensory evaluation}

Patty samples were cooked in an oven (ML32UW, LG Electronics, Korea). The oven was preset at $180^{\circ} \mathrm{C}$ for 20 min and internal temperature of the sample was monitored using a digital thermometer (YF-160A Type-K, YFE, Taiwan). The samples were turned over after $10 \mathrm{~min}$ of cooking $\left(60^{\circ} \mathrm{C}\right.$ internal temperature) and removed from the oven after a defined time when the internal temperature was $80^{\circ} \mathrm{C}$. The cooked beef patties were cut into 8 fan-shaped pieces that were placed on a white plate that was identified using a random 3-digit-code. The patties were served together with water. Nine panelists (five men, 23-31 years of age; four women, 23-33 years of age) evaluated the cooked samples for appearance, odor, taste, flavor, tenderness, juiciness, and acceptability based on a 9-point hedonic scale (from extremely dislike $=1$ to extremely like=9). The sensory evaluations were performed with patties storage for 0, 2 and 4 days. In each day, the sensory analysis was conducted in three individual trials with two observations. Patties were stored in refrigerator at $4{ }^{\circ} \mathrm{C}$ before sensory evaluation and used within 5 hrs.

\section{Texture analysis}

Texture analysis was conducted as described by Lee et al. (2017). Beef patties were cooked in an oven (ML32UW, LG Electronics) at the same cooking time and temperature used in the preparation for sensory evaluations. Those patties were stored at room temperature for $1 \mathrm{~h}$ to be cooled down. Samples were cut to obtain the same size (35 mm diameter, $25 \mathrm{~mm}$ height). The center of each sample was compressed twice to $60 \%$ of the original height using a texture analyzer (TA1, Lloyd Instruments Ltd, UK) with an attached compression probe $(7.5 \mathrm{~cm}$ diameter) at a test speed of $2 \mathrm{~mm} / \mathrm{s}$ and a trigger force of 1 $\mathrm{N}$. Hardness $(\mathrm{N})$, springiness $(\mathrm{mm})$, gumminess $(\mathrm{N})$, chewiness $(\mathrm{N})$, and cohesiveness were measured and recorded.

\section{Total aerobic bacterial counts}

Total aerobic bacterial counts of raw and cooked beef patties were analyzed as described by Yong et al. (2018). Samples (3 g) were each blended with $27 \mathrm{~mL}$ of sterile saline $(0.85 \%)$ for 2 min using a laboratory blender (BagMixer ${ }^{\circledR} 400 \mathrm{P}^{\text {, }}$ Interscience, France). Appropriate dilutions were prepared in sterile saline and spread on plate count agar (Difco Laboratories, USA). The agar plates were incubated at $37^{\circ} \mathrm{C}$ for $48 \mathrm{~h}$ and microbial counts were calculated. The results were expressed as Log numbers of colony-forming units per gram (Log CFU/g).

\section{Identification of microorganisms in crust}

Crust of the dry-aged beef were diluted with prepared sterile saline and appropriately spread on tryptic soy agar (TSA, Difco Laboratories, USA) and potato dextrose agar (PDA, Difco Laboratories, USA). Then, bacteria in TSA (Difco Laboratories, USA) and yeast/mold in PDA (Difco Laboratories) were identified using 16S rDNA and 18S rDNA sequencing, respectively (Kim et al., 2016a). The chromosomal DNA of isolated strain was separated using the BioFact Genomic DNA prep kit 
(BioFact, Korea). The DNA extracts were used for the polymerase chain reaction (PCR) with 1492R (5'-GGT TAC CTT GTT ACG ACT T-3') for bacteria and ITS4 (5'- TCC TCC GCT TAT TGA TAT GC-3') for yeast/mold, respectively. PCR was carried out in a LAMP-Taq programmable thermal cycler (BioFact) with one cycle of denaturation at $95^{\circ} \mathrm{C}$ for 15 min, followed by 30 cycles of $95^{\circ} \mathrm{C}$ for $20 \mathrm{~s}, 50^{\circ} \mathrm{C}$ for $40 \mathrm{~s}$, and $72^{\circ} \mathrm{C}$ for $90 \mathrm{~s}$. The final extension was carried out at $72^{\circ} \mathrm{C}$ for $5 \mathrm{~min}$. The purified PCR product obtained using a PCR purification kit (BioFact) was used for a Basic Local Alignment Search Tool (BLAST) search of sequences in the National Center for Biotechnology Information (NCBI) database (Maidak et al., 2000).

\section{Lipid oxidation}

2-Thiobarbituric acid reactive substances (TBARS) values were determined as described by Jung et al. (2011) to measure lipid oxidation. Each beef patty sample ( $3 \mathrm{~g})$ was homogenized with $9 \mathrm{~mL}$ distilled water using a T10 basic homogenizer. The homogenate $(2 \mathrm{~mL})$ was transferred to a test tube and mixed with $4 \mathrm{~mL}$ of 2-thiobarbituric acid $(0.02 \mathrm{M}) /$ trichloroacetic acid $(15 \%)$ solution. The test tubes were heated at $90^{\circ} \mathrm{C}$ in a water bath for $30 \mathrm{~min}$, cooled for 30 min in ice water, and centrifuged (Continent 512R, Hanil Co., Ltd., Korea) at 2,265×g for $10 \mathrm{~min}$. The absorbance of the supernatant was measured at $532 \mathrm{~nm}$ using an X-ma 3100 spectrophotometer. The amount of malondialdehyde (MDA) was calculated using a standard curve prepared from 1,1,3,3-tetraethoxypropane, and the TBARS value was reported as mg MDA per $\mathrm{kg}$ of sample.

\section{Statistical analysis}

All experimental procedures were repeated in three individual trials. Statistical analysis was performed by one-way Analysis of Variance (ANOVA) using the General Linear Model procedure. In sensory test, data for 3 different days were pooled and analyzed to see the effect of addition of the crust. Significant differences were identified with the StudentNewman-Keuls multiple-range test using Statistical Analysis System software (SAS 9.3, SAS Institute Inc., USA) at a confidence level of $\mathrm{p}<0.05$.

\section{Results and Discussion}

\section{Electronic nose and sensory evaluations}

The data from the electronic nose showed different patterns between patties formulated with 0 and $5 \%$ crust during storage (Fig. 1). In particular, ethanol, 2-methylfuran, and methylcyclopentane were more prevalent in patties with $5 \%$ crust than in control patties throughout storage. MacLeod and Ames (1986) reported that 2-methylfuran was related to slightly burnt rubber, sweet, buttery, and meaty-roast flavor in meat. In addition, methylcyclopentane was regarded as smoky, burnt rubber, sweet, buttery, and meaty-roast flavor.

Sensory scores of taste, flavor, tenderness, juiciness, and acceptability of beef patties made with 5\% crust were significantly higher than those of patties without crust (Table 2 , all $\mathrm{p}<0.05$ ). The appearance score of beef patties formulated with $5 \%$ crust were not significantly different than those of beef patties prepared without crust. The different sensory evaluation values between beef patties with and without 5\% crust were likely due to the crust, which is the beefy and palatable flavored surface of the dry-aged beef.

Kim et al. (2016b) described the increases in the contents of isoleucine, leucine, methionine, tryptophan, and valine during dry aging, which may indicate the rate of protein hydrolysis. The surface of dry-aged meat has excellent flavor due to the increased concentration of taste-related substances including free amino acids due to water evaporation and endogenous 


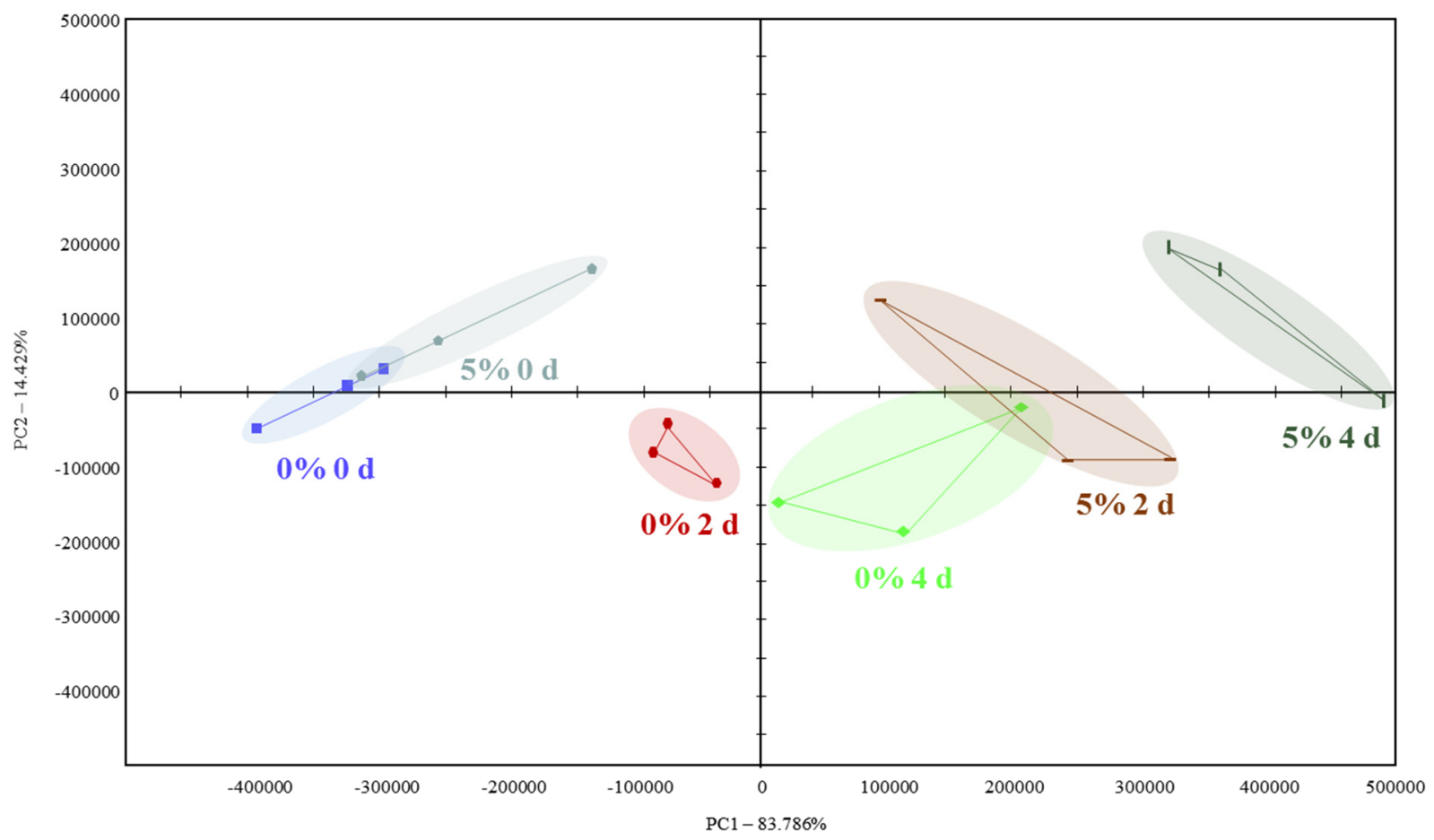

Fig. 1. Electronic nose analysis of cooked beef patties made with and without crust during storage.

Table 2. Sensory evaluation of beef patties added with the crust of dry-aged beef

\begin{tabular}{lccccccc}
\hline Addition of crust (\%) & Appearance & Odor & Taste & Flavor & Tenderness & Juiciness & Acceptability \\
0 & 5.63 & $5.44^{\mathrm{y}}$ & $5.70^{\mathrm{y}}$ & $5.56^{\mathrm{y}}$ & $5.48^{\mathrm{y}}$ & $5.19^{\mathrm{y}}$ & $5.78^{\mathrm{y}}$ \\
5 & 6.00 & $6.19^{\mathrm{x}}$ & $6.85^{\mathrm{x}}$ & $7.04^{\mathrm{x}}$ & $6.48^{\mathrm{x}}$ & $6.44^{\mathrm{x}}$ & $7.00^{\mathrm{x}}$ \\
SEM $^{1)}$ & 0.159 & 0.133 & 0.107 & 0.209 & 0.222 & 0.324 & 0.231 \\
\hline
\end{tabular}

1) Standard error of the means $(\mathrm{n}=6)$.

${ }^{\mathrm{x}, \mathrm{y}}$ Values with different letters within the same column differ significantly $(\mathrm{p}<0.05)$.

enzyme reaction. This improves the flavor of the meat (Ryu et al., 2018). Furthermore, some microorganisms, such as Penicillium camemberti and Debaryomyces hansenii, contribute to the flavor development of dry-aged beef (Lessard et al., 2012). These mechanisms of enhanced flavor may be markedly enhanced in the crust portion when compared with the inner flesh of dry-aged beef.

The difference between the tenderness of beef patty made with the crust and that without crust might be due to the hardness of the patty. The control patty was harder than that with crust at 3 and $7 \mathrm{~d}$ of storage by instrumental measurement (Table 3). In the present study, since the crust was lyophilized and pulverized before use it, the connective tissue of the crust could be broken down. Accordingly, it is possible that addition of this crust affects hardness and texture of the patty.

\section{Texture analysis}

Tenderness of a beef patty is one of the major sensory traits evaluated by consumers (Lee et al., 2017). In the present study, beef patties with $5 \%$ crust did not differ from patties without crust in terms of hardness, springiness, gumminess, chewiness, and cohesiveness on the initial day of storage (Table 3). However, patties with crust was associated with had significantly 
Table 3. Texture of cooked patties with and without crust during storage

\begin{tabular}{|c|c|c|c|c|c|}
\hline \multirow{2}{*}{ Texture parameters } & \multirow{2}{*}{ Addition of crust ( $\%)$} & \multicolumn{4}{|c|}{ Storage (d) } \\
\hline & & 0 & 3 & 7 & $\mathrm{SEM}^{1)}$ \\
\hline \multirow[t]{3}{*}{ Hardness $(\mathrm{N})$} & 0 & 159.14 & $199.00^{\mathrm{x}}$ & $197.89^{x}$ & 18.182 \\
\hline & 5 & 134.25 & $139.57^{y}$ & $111.59^{y}$ & 8.754 \\
\hline & $\mathrm{SEM}^{2)}$ & 19.523 & 9.374 & 11.907 & \\
\hline \multirow[t]{3}{*}{ Springiness (mm) } & 0 & 0.68 & 0.77 & 0.68 & 0.031 \\
\hline & 5 & 0.73 & 0.77 & 0.74 & 0.034 \\
\hline & $\mathrm{SEM}^{2)}$ & 0.040 & 0.026 & 0.030 & \\
\hline \multirow[t]{3}{*}{ Gumminess (N) } & 0 & 69.35 & $71.46^{\mathrm{x}}$ & $72.14^{\mathrm{x}}$ & 6.211 \\
\hline & 5 & $58.40^{\mathrm{a}}$ & $51.36^{\text {ay }}$ & $41.12^{\text {by }}$ & 2.994 \\
\hline & $\mathrm{SEM}^{2)}$ & 7.191 & 3.319 & 2.928 & \\
\hline \multirow[t]{3}{*}{ Chewiness (N) } & 0 & 45.44 & $55.11^{\mathrm{x}}$ & $49.01^{\mathrm{x}}$ & 4.046 \\
\hline & 5 & $42.45^{\mathrm{a}}$ & $39.55^{\text {ay }}$ & $30.05^{\text {by }}$ & 2.350 \\
\hline & $\mathrm{SEM}^{2)}$ & 3.670 & 3.364 & 2.837 & \\
\hline \multirow[t]{3}{*}{ Cohesiveness } & 0 & $0.45^{\mathrm{a}}$ & $0.36^{\mathrm{b}}$ & $0.37^{\mathrm{b}}$ & 0.017 \\
\hline & 5 & 0.44 & 0.37 & 0.37 & 0.019 \\
\hline & $\mathrm{SEM}^{2)}$ & 0.018 & 0.020 & 0.017 & \\
\hline
\end{tabular}

1) Standard error of the means $(n=18),{ }^{2)}(\mathrm{n}=12)$.

a,b Values with different letters within the same row differ significantly $(\mathrm{p}<0.05)$.

${ }^{\mathrm{x}, \mathrm{y}}$ Values with different letters within the same column differ significantly $(\mathrm{p}<0.05)$.

lower hardness, gumminess, and chewiness values than those without crust (all p<0.05) at 3 and $7 \mathrm{~d}$ of storage.

Ganhão et al. (2010) demonstrated that protein oxidation increases hardness in burger patties through the formation of protein carbonyls, loss of protein functionality, and formation of cross-links between proteins. If protein in beef patty is oxidized, then, it could be harder than that of none-oxidized counterpart. Some previous studies reported that small size peptides, which have various biological activities, were found in fermented protein foods due to its endogenous peptidases and/or microbial peptidases (Choe et al., 2018; Korhonen and Pihlanto, 2006; Toldrá et al., 2018). Liu et al. (2016) also reported some antioxidant peptides derived from meat muscle or processed meat products. Likewise, crust from dry-aged beef showed a higher antioxidant activity compared to lean meat and dry-aged meat in our previous study (data not shown). This antioxidant activity of crust can affect the protein oxidation and hardness of patty added with the crust. However, we cannot easily conclude that difference in hardness between control and crust-added patty were related to protein oxidation. Further study is needed to clarify the reason.

The texture of meat patties depends on various factors including condition of the raw meat, fat, water content, and type of additives (Kim et al., 2015). We expected that addition of the crust to beef patties would reduce the binding ability, because the crust was used after lyophilized. All the water inside in the crust was evaporated. Therefore, if only the crust is added to patties, texture of the beef patties would be affected not only by the crust but also by water content of the whole patties. Thus, water was added to patties in the present study to have similar water content in patties with control and treatment. Even though we adjusted the water content similar, there was a difference in the texture between them.

Total aerobic bacterial counts and identification of microorganisms in crust 
Numerous aerobic bacteria were detected in raw patties prepared with 5\% crust ( $4.5 \mathrm{Log}$ CFU/g) than those lacking crust (2.5 Log CFU/g) on the initial day of storage (Fig. 2). Total aerobic bacteria in raw patties with crust continuously increased to $8.4 \mathrm{Log} \mathrm{CFU} / \mathrm{g}$ after $6 \mathrm{~d}$ of storage $(\mathrm{p}<0.05)$.

The higher number of aerobic bacteria in patties made with $5 \%$ crust during storage might be attributed to the crust, which is the surface of dry-aged meat and is greatly affected by air-borne microorganisms. This speculation agrees with previous observations (Ryu et al., 2018) about the bacteria and fungi/yeast content on dry aged beef. The patties made with crust also showed rapid increase in the number of total aerobic bacteria by $6 \mathrm{~d}$ of storage. Li et al. (2013) reported that the total bacteria and yeast counts rapidly increased in dry-aged samples. In addition, the number of total aerobic bacteria was increased up to 5 Log values after 28 d of dry aging (Lee et al., 2017).

Although the total aerobic bacterial counts of raw patties with crust $6 \mathrm{~d}$ after storage were approximately $8 \mathrm{Log}$ CFU/g, pathogenic microorganisms were absent (Table 4). However, because the upper microbial limit for distribution of fresh meat in the market is $7 \mathrm{Log}$ CFU/g (ICMFS, 1974), control of the number of microorganisms is necessary and will be studied.

\section{Lipid oxidation}

MDA detected in beef patties indicates the level of lipid oxidation, which can be determined by the TBARS method (Kim et al., 2013). TBARS values were not different between the patties tested at $0 \mathrm{~d}$ (Table 5). However, significant differences

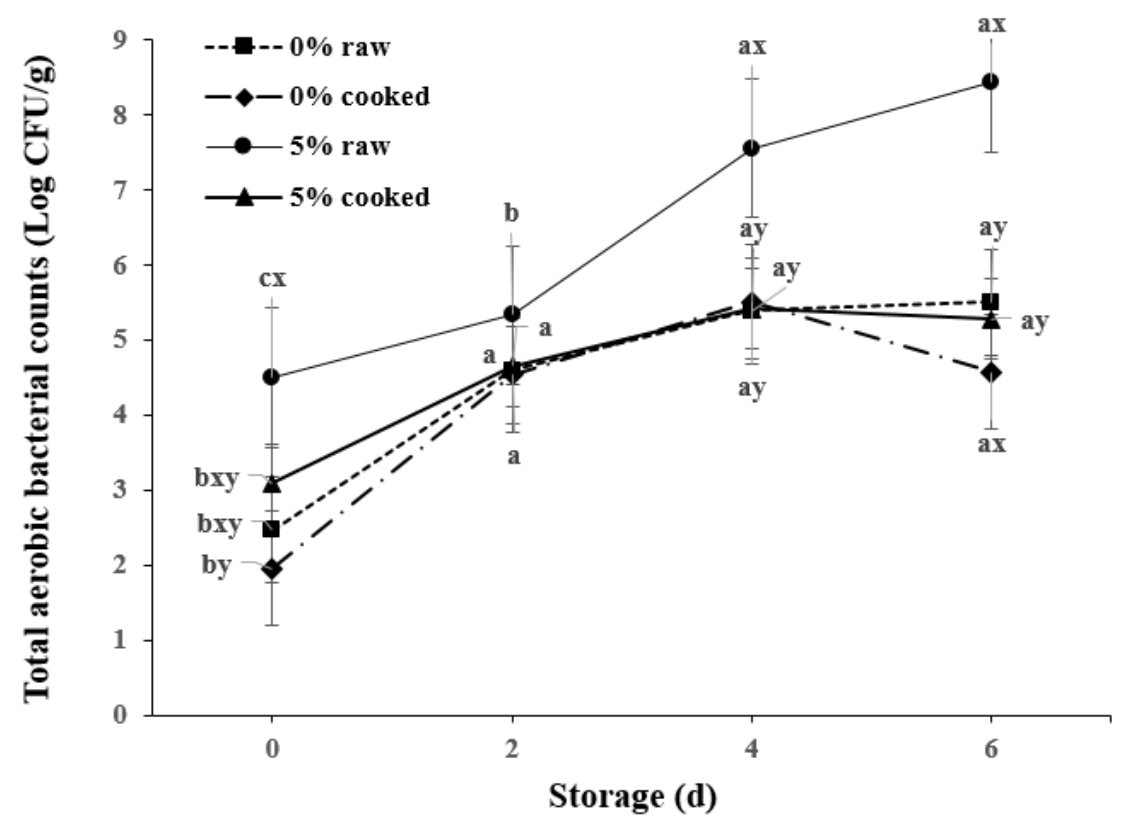

Fig. 2. Total aerobic bacterial counts (Log CFU/g) of raw and cooked beef patties with and without crust during storage. ${ }^{a-c}$ Values with different letters within treatment combination differ significantly $(p<0.05)$. ${ }^{x, y}$ Values with different letters within the same storage day differ significantly $(p<0.05)$.

Table 4. Identification of microorganisms in crust of the dry-aged beef

Microorganisms

Burkholderia lata, Leclercia adecarboxylate, Serratia grimesii,

Carnobacterium divergens, Cutaneotrichosporon curvatus, Candida zeylanoides,

Rhodotorula mucilaginosa 
Table 5. 2-Thiobarbituric acid reactive substances (TBARS) values ( $\mathrm{mg}$ malondialdehyde/ $\mathrm{kg}$ ) of raw beef patty with and without crust during storage

\begin{tabular}{lccccc}
\hline \multirow{2}{*}{ Addition of crust (\%) } & \multicolumn{5}{c}{ Storage $(\mathrm{d})$} \\
\cline { 2 - 6 } & 0 & 2 & 4 & 6 & SEM $^{1)}$ \\
0 & $1.00^{\mathrm{d}}$ & $1.16^{\mathrm{cx}}$ & $1.38^{\mathrm{b}}$ & $1.54^{\mathrm{ax}}$ & 0.028 \\
5 & $0.95^{\mathrm{c}}$ & $1.04^{\text {by }}$ & $1.33^{\mathrm{a}}$ & $1.35^{\text {ay }}$ & 0.027 \\
$\mathrm{SEM}^{2)}$ & 0.032 & 0.017 & 0.024 & 0.033 & \\
\hline
\end{tabular}

1) Standard error of the means $(\mathrm{n}=8),{ }^{2)}(\mathrm{n}=16)$.

${ }^{\mathrm{a}-\mathrm{d}}$ Values with different letters within the same row differ significantly $(\mathrm{p}<0.05)$.

${ }^{x, y}$ Values with different letters within the same column differ significantly $(\mathrm{p}<0.05)$.

were observed after $2 \mathrm{~d}$ of storage $(\mathrm{p}<0.05)$. In addition, TBARS values were gradually increased during $6 \mathrm{~d}$ of storage in both types of patties, particularly in patties without crust.

These could be due to the interaction between microorganisms and MDA. MDA removal or loss might occur through direct microbial utilization of MDA and other TBARS (Rhee et al., 1997). As shown in Fig. 2, patties made with 5\% crust contained greater numbers of aerobic bacteria than patties made without crust during the $6 \mathrm{~d}$ of storage.

The relatively less pronounced increase in TBARS value for beef patties made with $5 \%$ crust compared to crust-free patties might be partially explained by the antioxidant activity of the crust. Several bioactive peptides are generated from meat and meat products during dry fermentation or aging with protease treatment (Gallego et al., 2018; Seol et al., 2018). We have observed antioxidant activity of crust (data not shown). The addition of materials with antioxidant activity can reduce the TBARS value in beef patty (Rojas and Brewer, 2007). This might apply to crust. However, this is not conclusive and more studies of the functionality of the crust of dry-aged beef are needed.

\section{Conclusions}

Sensory evaluation of beef patties made with 5\% crust from dry-aged beef revealed significantly higher taste, flavor, and tenderness compared to crust-free patties. This difference was evident in both by electronic nose and texture analyses. Therefore, the crust from dry-aged beef could be a flavor enhancer in meat products by providing beefy and palatable flavor without a long period of dry aging as is commonly practiced. However, the microbial safety of the crust should be reconfirmed prior to utilization in different dry-aging practices.

\section{Acknowledgements}

This study was supported by "High Value-added Food Technology Development Program (Project No. 316048)," Korea Institute of Planning and Evaluation for Technology in Food, Agriculture, Forestry and Fisheries. Also, this work was supported by the BK21 Plus Program of the Department of Agricultural Biotechnology, Seoul National University, Seoul, Korea.

\section{References}

Choe J, Seol KH, Kim HJ, Hwang JT, Lee M, Jo C. 2018. Isolation and identification of angiotensin I-converting enzyme (ACE) inhibitory peptides derived from thermolysin-injected Hanwoo M. longissimus. Asian Australas J Anim Sci doi: 
10.5713/ajas.18.0455.

DeGeer SL, Hunt MC, Bratcher CL, Crozier-Dodson BA, Johnson DE, Stika JF. 2009. Effects of dry aging of bone-in and boneless strip loins using two aging processes for two aging times. Meat Sci 83:768-774.

Dikeman ME, Obuz E, Gök V, Akkaya L, Stroda S. 2013. Effects of dry, vacuum, and special bag aging; USDA quality grade; and end-point temperature on yields and eating quality of beef Longissimus lumborum steaks. Meat Sci 94:228233.

Gallego M, Mora L, Escudero E, Toldrá F. 2018. Bioactive peptides and free amino acids profiles in different types of European dry-fermented sausages. Int J Food Microbiol 276:71-78.

Ganhão R, Morcuende D, Estévez M. 2010. Protein oxidation in emulsified cooked burger patties with added fruit extracts: Influence on colour and texture deterioration during chill storage. Meat Sci 85:402-409.

Gorraiz C, Beriain MJ, Chasco J, Insausti K. 2002. Effect of aging time on volatile compounds, odor, and flavor of cooked beef from Pirenaica and Friesian bulls and heifers. J Food Sci 67:916-922.

Hodges JH, Cahill VR, Ockerman HW. 1974. Effect of vacuum packaging on weight loss, microbial growth and palatability of fresh beef wholesale cuts. J Food Sci 39:143-146.

ICMFS. 1974. Microorganisms in Foods. 2. Sampling for microbiological analysis: Principles and specific applications. $2^{\text {nd }}$ ed. University of Toronto Press, Toronto, USA.

Parrish FC Jr., Boles JA, Rust RE, Olson DG. 1991. Dry and wet aging effects on palatability attributes of beef loin and rib steaks from three quality grades. J Food Sci 56:601-603.

Jung YK, Jeon HJ, Jung S, Choe JH, Lee JH, Heo KN, Kang BS, Jo C. 2011. Comparison of quality traits of thigh meat from Korean native chickens and broilers. Korean J Food Sci An 31:684-692.

Kim HJ, Yong HI, Lee HJ, Jung S, Kwon JH, Heo KN, Jo C. 2016a. Identification of microorganisms in duck meat products available in Korea and the effect of high hydrostatic pressure. Korean J Food Sci An 36:283-288.

Kim MH, Joo SH, Choi HY. 2015. The effect of aronia powder (Aronia melanocarpa) on antioxidant activity and quality characteristics of pork patties. Korean J Food Cook Sci 31:83-90.

Kim SJ, Cho AR, Han J. 2013. Antioxidant and antimicrobial activities of leafy green vegetable extracts and their applications to meat product preservation. Food Control 29:112-120.

Kim YHB, Kemp R., Samuelsson LM. 2016b. Effects of dry-aging on meat quality attributes and metabolite profiles of beef loins. Meat Sci 111:168-176.

Korhonen H, Pihlanto A. 2006. Bioactive peptides: Production and functionality. Int Dairy J 16: 945-960.

Lee HJ, Choe J, Kim KT, Oh J, Lee DG, Kwon KM, Choi YI, Jo C. 2017. Analysis of low-marbled Hanwoo cow meat aged with different dry-aging methods. Asian Australas J Anim Sci 30:1733-1738.

Lessard MH, Bélanger G, St-Gelais D, Labrie S. 2012. The composition of camembert cheese-ripening cultures modulates both mycelial growth and appearance. Appl Environ Microbiol 78:1813-1819.

Li X, Babol J, Wallby A, Lundström K. 2013. Meat quality, microbiological status and consumer preference of beef gluteus medius aged in a dry ageing bag or vacuum. Meat Sci 95:229-234.

Liu R, Xing L, Fu Q, Zhou G, Zhang W. 2016. A review of antioxidant peptides derived from meat muscle and by-products. Antioxidants 5:32

MacLeod G, Ames JM. 1986. The effect of heat on beef aroma: Comparisons of chemical composition and sensory properties. Flavour Frag J 1:91-104. 
Maidak BL, Cole JR, Lilburn TG, Parker CT Jr., Saxman PR, Farris RJ, Stredwick JM, Garrity GM, Li B, Olsen GJ, Pramanik S, Schnidt TM, Tiedje JM. 2000. The RDP (Ribosomal Database Project) continues. Nucleic Acids Res 28:173174.

Myers N, Kent J. 2003. New consumers: The influence of affluence on the environment. Proc Natl Acad Sci U.S.A. 100:4963-4968.

Oh J, Lee HJ, Kim HC, Kim HJ, Yun YG, Kim KT, Choi YI, Jo C. 2017. The effects of dry or wet aging on the quality of the longissimus muscle from 4-year-old Hanwoo cows and 28-month-old Hanwoo steers. Anim Prod Sci. doi:10.1071/ AN17104.

Rhee KS, Krahl LM, Lucia LM, Acuff GR. 1997. Antioxidant/antimicrobial effects and TBARS in aerobically refrigerated beef as related to microbial growth. J Food Sci 62:1205-1210.

Rojas MC, Brewer MS. 2007. Effect of natural antioxidants on oxidative stability of cooked, refrigerated beef and pork. J Food Sci 72:S282-S288.

Ryu S, Park MR, Maburutse BE, Lee WJ, Park DJ, Cho S, Hwang I, Oh S, Kim Y. 2018. Diversity and characteristics of the meat microbiological community on dry aged beef. J Microbiol Biotechnol 28:105-108.

Smith RD, Nicholson KL, Nicholson JDW, Harris KB, Miller RK, Griffin DB, Savell JW. 2008. Dry versus wet aging of beef: Retail cutting yields and consumer palatability evaluations of steaks from US choice and US select short loins. Meat Sci 79:631-639.

Seol KH, Choe J, Kim HJ, Hwang JT, Lee M, Jo C. 2018. Bioactivities of peptide fractions derived from proteolytic enzymeinjected Hanwoo longissimus muscle in a model system. Int J Food Prop 21:205-212.

Toldrá F, Reig M, Aristoy MC, Mora L. 2018. Generation of bioactive peptides during food processing. Food Chem 267:395404.

Yong HI, Park J, Kim HJ, Jung S, Park S, Lee HJ, Choe W, Jo C. 2018. An innovative curing process with plasma-treated water for production of loin ham and for its quality and safety. Plasma Process Polym 15:1700050.

Zhang W, Maheswarappa NB, Jo C, Sakata R, Zhou G, Banerjee R, Nishiumi T. 2017. Technological demands of meat processing-An Asian perspective. Meat Sci 132:35-44. 